\title{
The Benefits and Impacts of Multi-Level Emission Standards on the Fuel Economy Characteristics of Small and Large Cars
}

\author{
Prepared by
}

The Mobile Systems Group

31 March 1976

Prepared for

U. S. ENERGY RESEARCH AND DEVELOPMENT ADMINISTRATION

Transportation Energy Conservation Division

W ashington, D. C.

Contract No. E(04-3)-1101, PA-3

Environment and Energy Conservation Division THE AEROSPACE CORPORATION 


\section{DISCLAIMER}

This report was prepared as an account of work sponsored by an agency of the United States Government. Neither the United States Government nor any agency Thereof, nor any of their employees, makes any warranty, express or implied, or assumes any legal liability or responsibility for the accuracy, completeness, or usefulness of any information, apparatus, product, or process disclosed, or represents that its use would not infringe privately owned rights. Reference herein to any specific commercial product, process, or service by trade name, trademark, manufacturer, or otherwise does not necessarily constitute or imply its endorsement, recommendation, or favoring by the United States Government or any agency thereof. The views and opinions of authors expressed herein do not necessarily state or reflect those of the United States Government or any agency thereof. 


\section{DISCLAIMER}

Portions of this document may be illegible in electronic image products. Images are produced from the best available original document. 
Aerospace Report No. ATR-76(7380)-1

THE BENEFITS AND IMPACTS OF MULTI-LEVEL EMISSION STANDARDS ON THE FUEL ECONOMY CHARACTERISTICS OF SMALL AND LARGE CARS

\author{
Prepared by \\ The Mobile Systems Group \\ Environment and Energy Conservation Division \\ THE AEROSPACE CORPORATION \\ E1 Segundo, California 90245
}

$31 \mathrm{March} 1976$

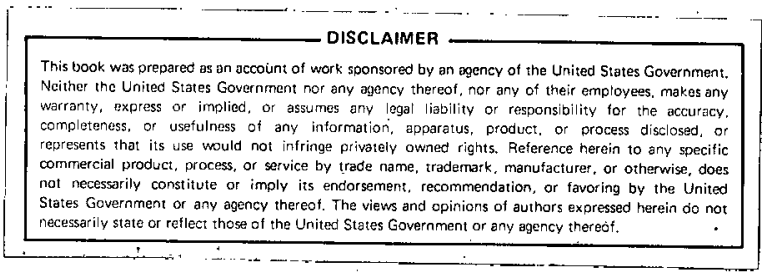

Prepared for

U.S. ENERGY RESEARCH AND DEVELOPMENT ADMINISTRATION:

Transportation Energy Conservation Division

Wàshington, D. C.

Contract No. E(04-3)-1101, PA-3

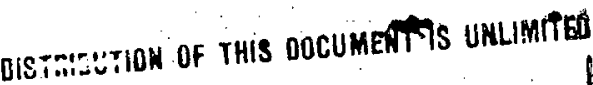




\section{THIS PAGE \\ WAS INTENTIONALLY \\ LEFT BLANK}


ACKNOWLEDGMENTS

Appreciation is acknowledged for the guidance and assistance provided by Mr. Graham Hagey of the Energy Research and Development Administration, Transportation Energy Conservation Division, who served as Program Manager for this study.

Mr. Wolfgang Roessler and Mr. Ronald Covey of The Aerospace Corporation made valuable contributions to the study.

Merrill friction

Merrill G. Hinton, Group Director

Mobile Systems

Environment and Energy

Conservation Division

Approved by

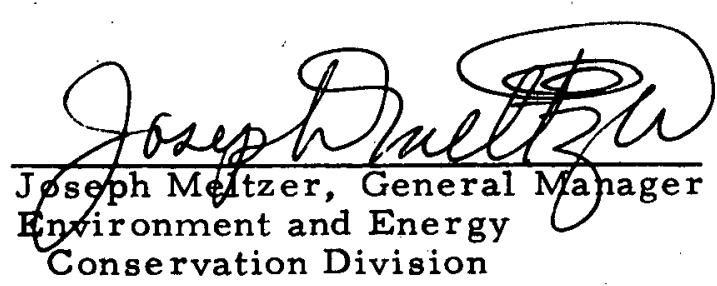

iii 


\section{THIS PAGE \\ WAS INTENTIONALLY \\ LEFT BLANK}




\section{FOREWORD}

This report, prepared by The Aerospace Corporation for the U.S. Energy Research and Development Administration (ERDA), Division of Transportation Energy Conservation, presents the results of a brief review of the fuel economy and emission characteristics of small and large cars to determine whether or not it is meaningful to implement multi-level emission regulations to enable an overall fuel economy improvement for the total vehicle fleet.

A concise review of important findings is presented in Section 1. Section 2 presents a brief review of the technical background and the rationale for the study effort. The results of a survey of the variation of fuel economy and exhaust emissions as a function of vehicle inertia test weight a re presented in Section 3. Section 4 discusses the resultant effects of catalyst and non-catalyst use on both emissions and fuel economy for both large and small cars. 


\section{THIS PAGE \\ WAS INTENTIONALLY \\ LEFT BLANK}




\section{CONTENTS}

\section{ACKNOWLEDGMENTS}

FOREWORD

1. SUMMARY 1

2. INTRODUCTION AND BACKGROUND 3

3. VARIATION OF FUEL ECONOMY AND EMISSIONS AS

A FUNCTION OF VEHICLE INERTIA TEST WEIGHT

3.1 Fuel Economy 7

3.2 Emissions 9

4. CATALYST VS. NON-CATALYST EFFECTS 15

4.1 Large Cars 15

4.2 Small Cars 16

4. 3 Summary Remarks 19

REFERENCES 


\section{FIGURES}

1. Exhaust Flow vs Inertia Test Weight (Based on 7-Mode Federal Test Procedure)

2. Permitted Pollutant Concentration vs Inertia Test Weight (Based on 7-Mode Federal Test Procedure Exhaust Volume Flow Rates)

3. Break-Even Factor for Emissions and Fuel Economy as a Function of Inertia Test Weight (Based on Constant Concentrations for All Inertia Test Weights)

4. 1973 Certification Vehicles: Fuel Consumption Variation with Inertia Test Weight, Non-Catalyst Vehicles

5. 1975 California Certification Vehicles: Fuel Consumption vs Inertia Test Weight (Catalyst-Equipped, Automatic

Transmissions, Based on EPA Urban Cycle)

6. $\quad 1976$ California Certification Vehicles: Fuel Consumption vs Inertia Test Weight (Catalyst-Equipped, Automatic and Manual Transmissions, Based on EPA Urban Cycle)

7. 1973 Certification Vehicles: Variation of Emissions with Ine rtia Test Weight, Non-Catalyst Vehicles

8. 1975 California Certification Vehicles: Variation of Emissions with Inertia Test Weight, Catalyst Vehicles

9. 1976 California Certification Vehicles: Variation of

Emissions with Inertia Test Weight, Catalyst Vehicles

10. Maximum Fuel Economy CVS-H Projections Study No. 2 (5000-lb Inertia Test Weight Vehicle)

11. Impact of Catalyst Use on Fuel Economy at 1975-76

Emission Levels (5000-1b Inertia Test Weight Vehicle)

12. Impact of Catalyst Use on Fuel Economy at 1975-76

Emission Levels (2250-1b Inertia Test Weight Vehicle)

T ABLE

1. 1976 Certification Vehicles: Catalyst vs Non-catalyst Mix 


\section{SECTION 1}

\section{SUMMARY}

The need to meet the 1975-76 passenger car hydrocarbon (HC) and carbon monoxide (CO) exhaust emission standards for both California and the 49 states has required the use of oxidation catalysts on most large cars. [These standards, and those for oxides of nitrogen ( $N O_{x}$ ), are for California and the 49 states, respectively: $\mathrm{HC}=0.9 / 1.5 \mathrm{grams}$ per $\mathrm{mile}(\mathrm{gr} / \mathrm{mi})$, $\mathrm{CO}=9 / 15 \mathrm{gr} / \mathrm{mi}, \mathrm{NO}_{\mathbf{x}}=2 / 3.1 \mathrm{gr} / \mathrm{mi}$ ]. Use of the se catalysts has been accompanied by improved fuel economy since they permit the engine ignition timing to be advanced (spark retard had been a principal control technique for HC prior to the catalyst).

The extent of the use of the catalyst on smaller cars was not known with certainty, since they could meet the emission standards more easily because of lower exhaust flow rates that permitted higher pollutant concentration levels. But if they were not using catalysts--with their associated fuel economy improvement--then the question arises as to whether it is meaningful to implement multi-level emission regulations (different values for small and large cars) to encourage or force such equipment changes on smaller cars, and by so doing improve the overall fuel economy of the total fleet while at the same time reduce overall emissions.

Therefore, a brief review of the small car vs. large car fuel economy and emission scenario was conducted to provide a perspective for resolution of this issue. The highlights of this review are briefly summarized below:

a. The 1975-76 federal HC standard (1.5 gr/mi) is sufficiently low to effectively force the use of catalysts on larger cars (4000-1b inertia test weight and above) to avoid fuel economy losses, but not sufficiently low to require them on all smaller cars (3500-1b class and below). However, the 1975-76 
California HC standard $(0.9 \mathrm{gr} / \mathrm{mi})$ is sufficiently low to do s.o, as evidenced by the fact that essentially all

California cars do use catalysts.

b. Whether or not small or large cars are equipped with oxidation catalysts, $\mathrm{NO}_{\mathbf{x}}$ standards below the current federal level ( $3.1 \mathrm{gr} / \mathrm{mi}$ ) and California level ( $2 \mathrm{gr} / \mathrm{mi}$ ) will act to reduce vehicle fuel economy, although small cars are slightly less sensitive in this respect.

c. To meet the projected federal and California HC standard of $0.41 \mathrm{gr} / \mathrm{mi}$, both small and large cars will be forced to use catalysts, since this is the only available emission control technique for the conventional spark ignition engine.

d. To ensure the fuel economy and emission benefits of catalysts, ERDA need only support the implementation of the proposed HC standard of $0.41 \mathrm{gr} / \mathrm{mi}$. Making the federal standard the same as the California one would also produce this result. 


\section{SECTION 2}

\section{INTRODUCTION AND B ACKGROUND}

The original passenger car exhaust emission standards, commencing in 1966 in California and in 1968 for the rest of the nation, were based on the 7 -mode federal test procedure. This test procedure involved dynamometer testing of a fully warmed-up vehicle at selected operating conditions (steadystate speeds, accelerations, decelerations, idle) which we re "weighted" to represent a composite of an urban driving pattern derived from driving tests in Los Angeles; i.e., the LA-4 route. Although the emission standards were expressed in terms of grams per vehicle mile, the actual measurements of pollutants were based on the concentration of the individual species (HC, CO) in the exhaust stream, in terms of parts per million for $\mathrm{HC}$ and percent for CO. The pollutant concentration was converted to a mass basis by using an equation to determine the exhaust flow of each vehicle as a function of the inertia test weight, with the resulting variation as shown in Figure 1.

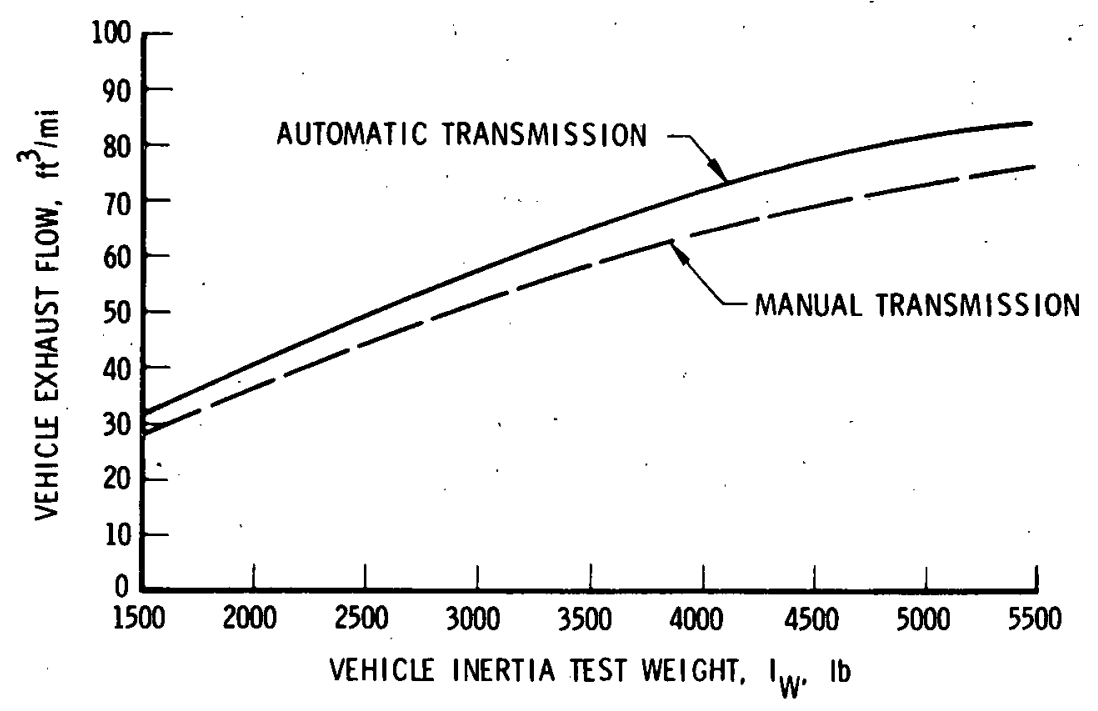

Figure 1. Exhaust Flow vs Inertia Test Weight (Based on 7-Mode Federal Test Procedure) (Ref. 1) 
Since the emission standards in grams per mile were the same for both small and large cars, the lower exhaust flow rates of the smaller inertia weight vehicles permitted higher pollutant concentrations in their exhaust; Figure 2 illustrates this characteristic on a normalized ratio basis. Although the federal test procedures have been revised to incorporate the constantvolume-sampling (CVS) test procedure, wherein a portion of the exhaust is collected in bags, and the driving cycle has been altered to reflect both hot and cold start conditions, the standards are still expressed in grams per mile and are the same for both large and small vehicles.

\section{CONSTANT POLLUTANT MASS FLOW RATE IN gr/mi}

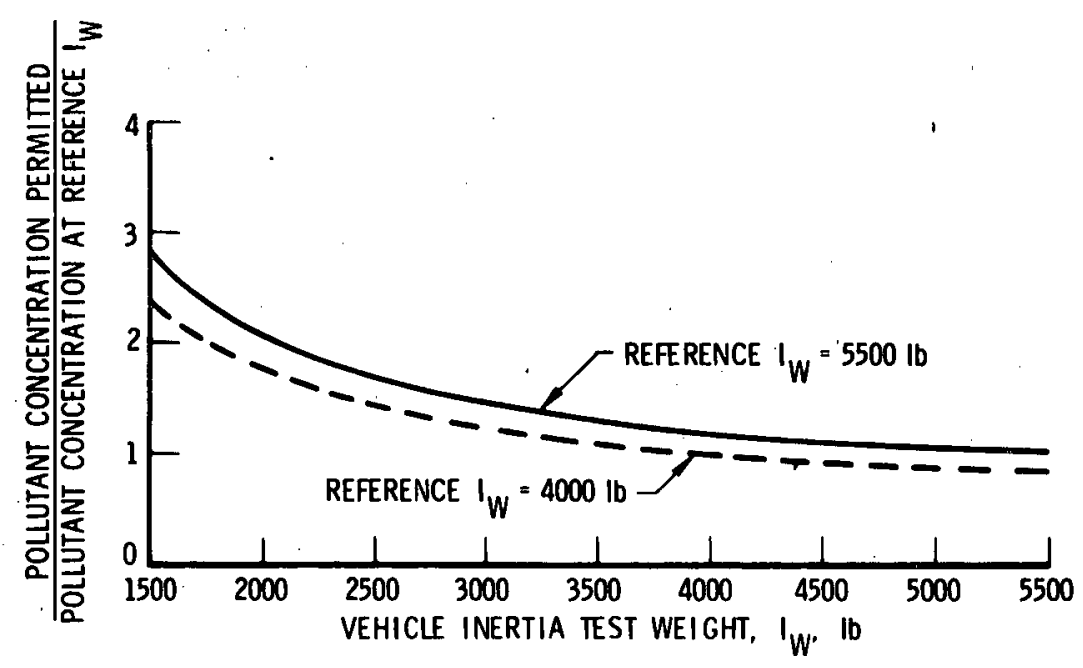

Figure 2. Permitted Pollutant Concentration vs Inertia Test Weight (Based on 7 -Mode Federal Test Procedure Exhaust Volume Flow Rates)

The more stringent emission standards for the 1975-76 model years in both California ( $\mathrm{HC}=0.9 \mathrm{gr} / \mathrm{mi}, \mathrm{CO}=9 \mathrm{gr} / \mathrm{mi}, \mathrm{NO}=2 \mathrm{gr} / \mathrm{mi}$ ) and the 49 states ( $\mathrm{HC}=1.5 \mathrm{gr} / \mathrm{mi}, \mathrm{CO}=15 \mathrm{gr} / \mathrm{mi}, \mathrm{NO}_{\mathrm{x}}=3.1 \mathrm{gr} / \mathrm{mi}$ ) have resulted 
in the use of oxidation catalysts on most large cars to meet the $\mathrm{HC}$ and $\mathrm{CO}$ limits. Incorporation of the se catalysts permitted an advance in engine ignition timing with a resultant improvement in fuel economy (spark retard had been a principal control technique for $\mathrm{HC}$ control prior to the catalyst). It was not known with certainty what the corresponding picture was with the smaller cars, which could meet the emission standards more easily (i.e., without catalysts) because of the higher permitted pollutant concentration levels. If they we re not using catalysts--with the associated improved fuel economy--then the question arises as to whether it is meaningful to implement multi-level emission regulations (different values for small and large cars) to encourage or force such equipment changes on smaller cars and thus enable an improvement in overall fuel economy of the total vehicle fleet while at the same time reducing overall exhaust emissions.

Therefore, a brief review of the small car vs. large car fuel economy and emission scenario was conducted to provide a perspective for resolution of this question. The results are briefly summarized in the following sections. 


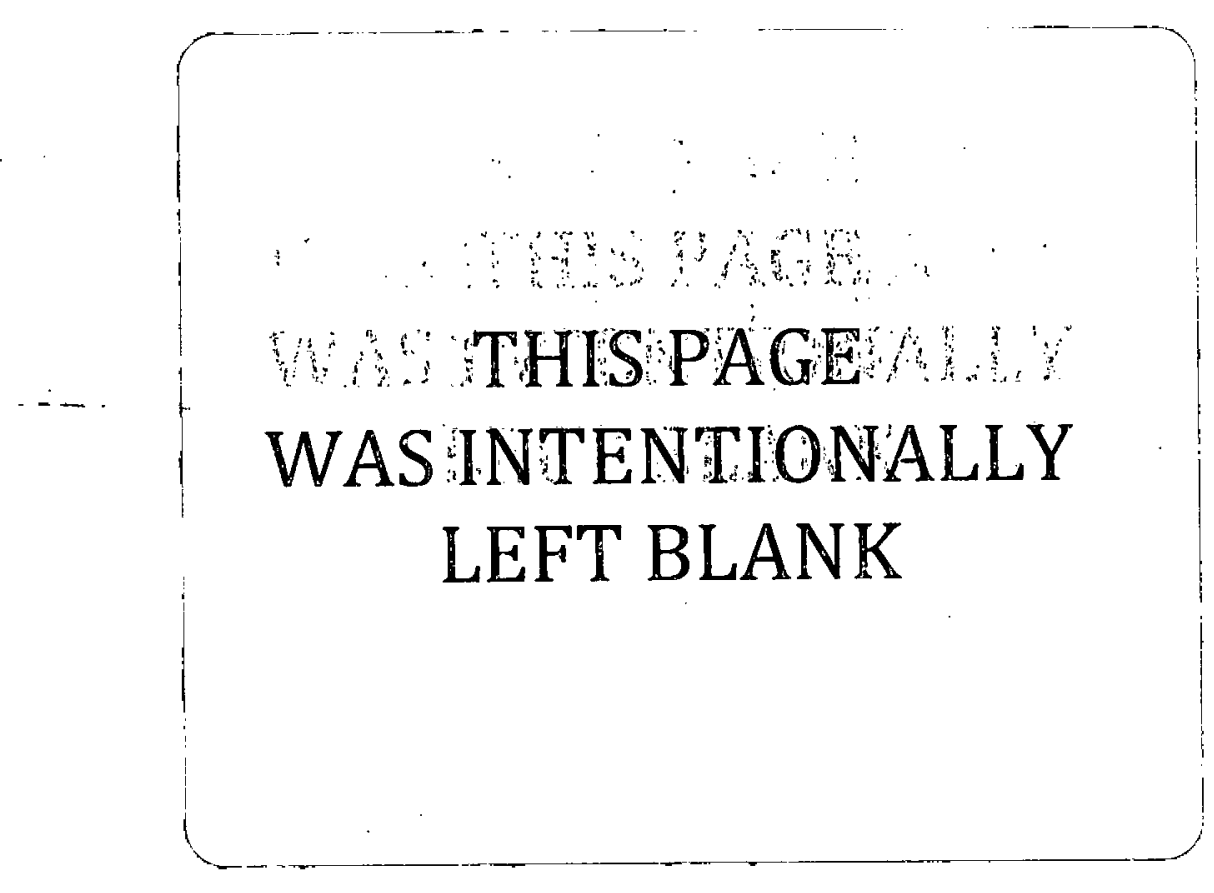

6 


\section{SECTION 3}

\section{VARIATION OF FUEL ECONOMY AND EMISSIONS AS A FUNCTION OF VEHICLE INERTIA TEST WEIGHT}

Since to a first approximation the mass emissions and mass fuel consumption (the inverse of miles per gallon) are directly proportional to exhaust mass flow, this relationship was selected to form the basis of comparison between cars of different inertia test weights $\left(I_{w}\right)$. As illustrated in Figure 3, a break-even factor is defined and normalized by reference to the $I_{w}$ value of $4500 \mathrm{lb}$ which has a value of 1.0. The "break-even" line is simply the ratio of vehicle exhaust flows (from Figure 1) at any $I_{w}$ divided by the exhaust flow at $I_{w}=4500 \mathrm{lb}$. On this line, then, the pollutant or fuel consumption concentrations are equal. Any values obtained or reported which lie below the line indicate that the concentration of the emissions in the exhaust or the fuel in the intake air is lower than that for the reference $I_{w}$; i.e., the emissions or fuel economy are better when points lie below the break-even line. This basis of comparison is used in the series of figures which follow.

\subsection{FUEL ECONOMY}

Figure 4 illustrates the variation of fuel consumption with $I_{w}$ for the certification test vehicles for the 1973 model year, prior to the introduction of oxidation catalysts. At this time, the $\mathrm{NO}_{\mathrm{x}}$ standard $(3.0 \mathrm{gr} / \mathrm{mi}$ on the CVS-C test procedure) was equivalent to the federal 1975-76 $\mathrm{NO}_{x}$ standard (3.1 $\mathrm{gr} / \mathrm{mi}$ on the CVS-CH test procedure). As can be seen, the vehicles below $I_{w}=30001 \mathrm{~b}$ have lower fuel consumption [ $[$ i.e., higher fuel economy in miles per gallon ( $\mathrm{mpg}$ )] than would be expected on the basis of equivalency. 


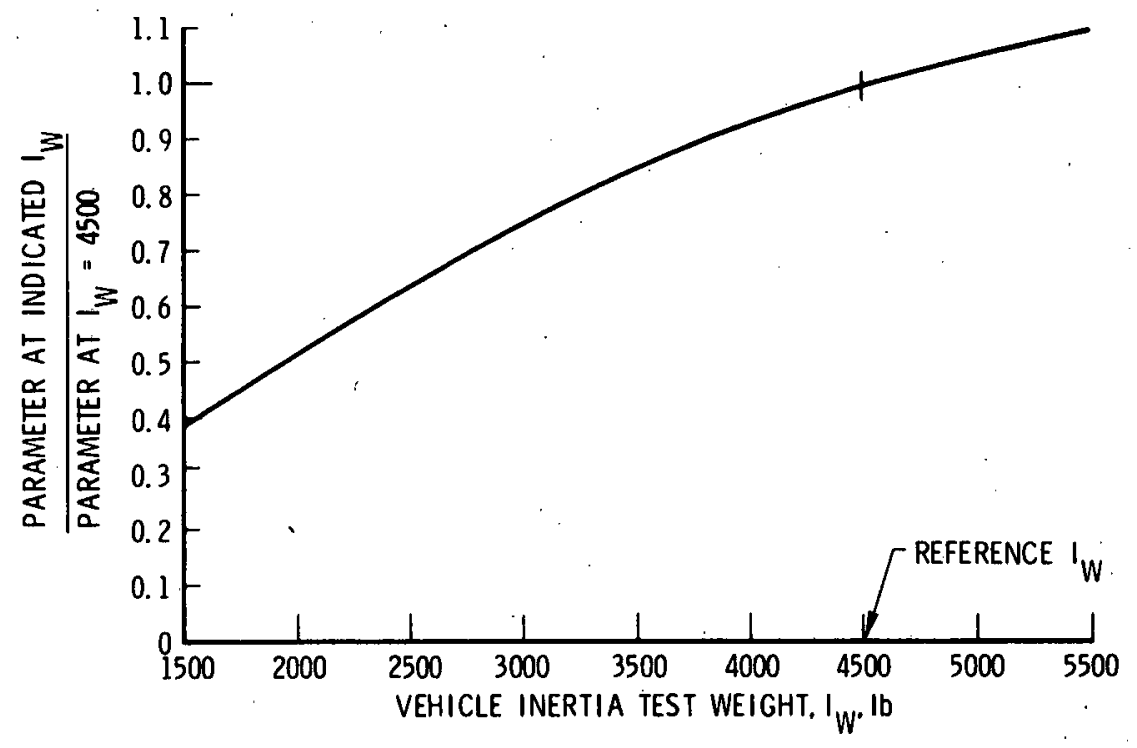

Figure 3. Break-Even Factor for Emissions and Fuel Economy as a Function of Inertia Test Weight (Based on Constant Concentrations for All Inertia Test Weights)

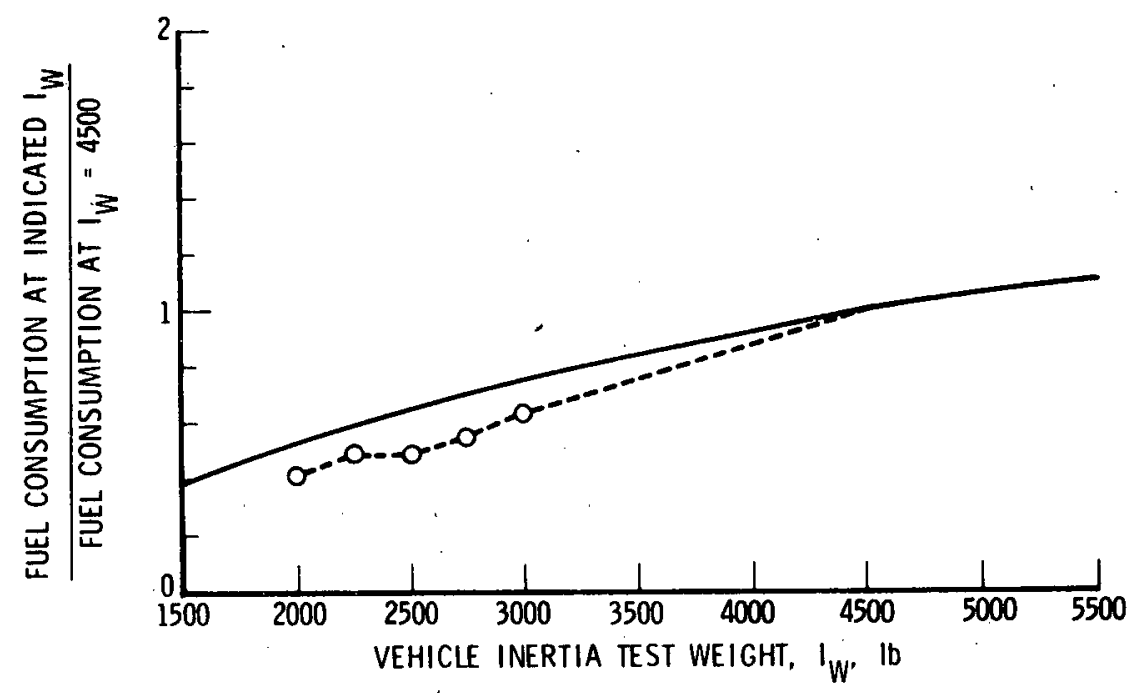

Figure 4. 1973 Certification Vehicles: Fuel Consumption Variation with Inertia Test Weight, Non-Catalyst Vehicles (Ref. 2) 
This is due to the fact that these smaller vehicles have lower horsepowerto-weight ratios and consequently operate at more efficient high meaneffective-cylinder pressures than the larger vehicles.

Figures 5 and 6 show the same factors for catalyst-equipped vehicles in California in the 1975 and 1976 model years. As can be noted, the 3000-1b and below $I_{w}$ classes exhibit approximately the same fuel economy performance as before the addition of the catalyst, even though the $\mathrm{NO}_{\mathbf{x}}$ standard in California was lowered to $2 \mathrm{gr} / \mathrm{mi}$ in 1975-76.

\section{$3.2 \quad$ EMISSIONS}

Figure 7 illustrates the variation of $\mathrm{HC}, \mathrm{CO}$, and $\mathrm{NO}_{\mathbf{x}}$ with $\mathrm{I}_{\mathrm{w}}$ for the certification test vehicles for the 1973 model year, prior to the introduction of oxidation catalysts. In this case, the $H C$ and $C O$ values of vehicles in the $I_{w}=30001 \mathrm{~b}$ and below classes were essentially the same as those for larger vehicles, in terms of grams per mile. Thus their pollutant concentrations, in parts per million or percent, lie above the concentration equivalency line, as permitted by existing regulations. This implies that the vehicle manufacturers retarded ignition timing just enough to meet the standards (with deterioration and manufacturing margins) in the interest of fuel economy.

The $\mathrm{NO}_{x}$ value trends of small cars are less than those of large cars, in terms of grams per mile, but higher in terms of parts per million, or concentration. This is a natural result of the smaller engines operating at higher engine loadings, which produces more $\mathrm{NO}_{\mathbf{x}}$ on a concentration basis. It should be noted, as mentioned above, that these same higher engine loadings result in improved fuel economy, at the expense, however, of increased NO $x$ concentration. 


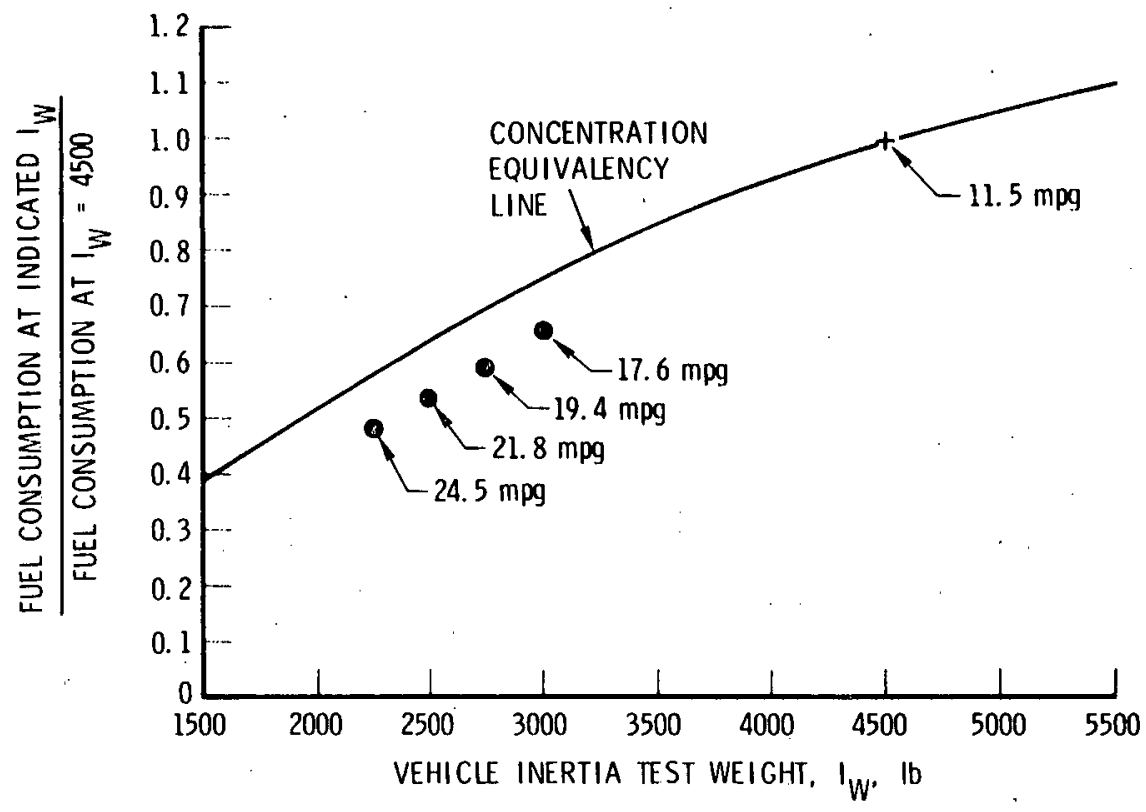

Figure 5. 1975 California Certification Vehicles: Fuel Consumption vs Inertia Test Weight (Catalyst-Equipped, Automatic Transmissions, Based on EPA Urban Cycle) (Ref. 3)

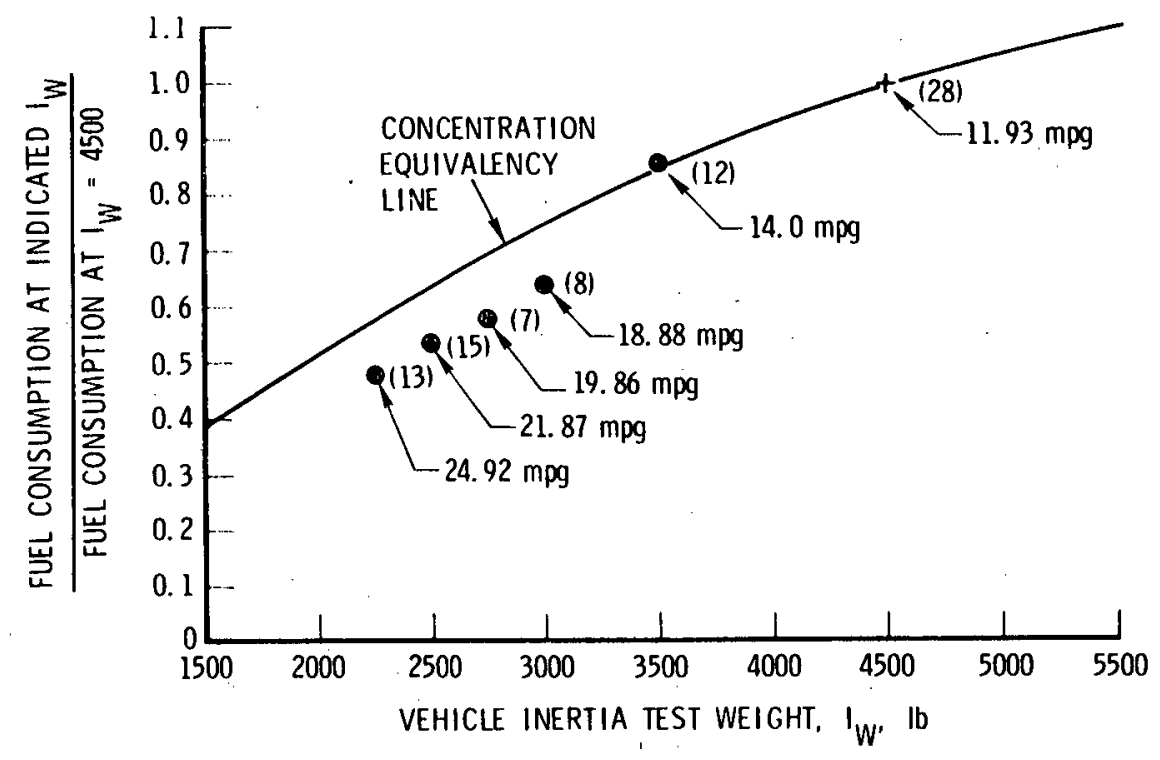

Figure 6. 1976 California Certification Vehicles: Fuel Consumption vs Inertia Test Weight (Catalyst-Equipped, Automatic and Manual Transmissions, Based on EPA Urban Cycle) (Ref. 4) 


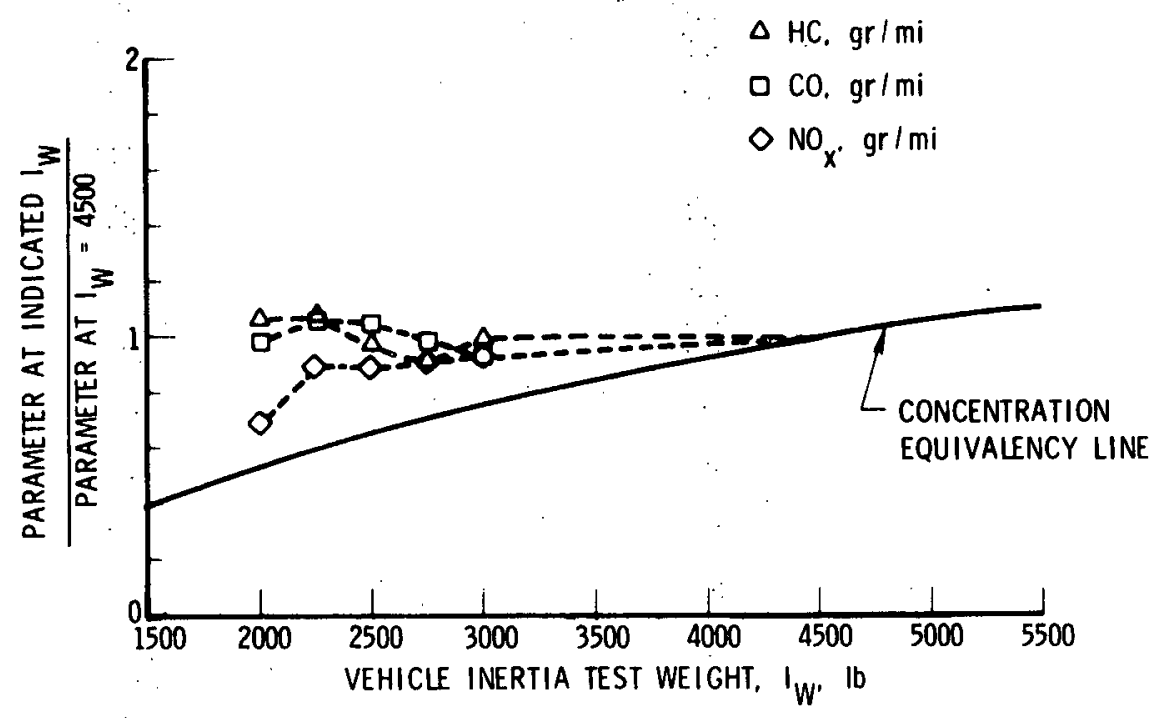

Figure 7. 1973 Certification Vehicles: Variation of Emissions with Inertia Test Weight, Non-Catalyst Vehicles (Ref. 2)

Figure 8 shows the variation with $\mathrm{I}_{\mathrm{w}}$ of $\mathrm{HC}, \mathrm{CO}$, and $\mathrm{NO}_{\mathrm{x}}$ emissions, respectively, for the 1975 model year in California and Figure 9 shows similar characteristics for the 1976 model year. With the addition of oxidation catalysts, on the average, it appears that the smaller cars are producing HC concentrations equivalent to those for larger vehicles; i.e., less HC in terms of grams per mile. This same trend is shown for $\mathrm{CO}$ in the 1975 model year, with somewhat higher concentrations in the 1976 model year. Normally, one expects $\mathrm{HC}$ and $\mathrm{CO}$ trends to be similar. However, it is well known that $\mathrm{CO}$ is very sensitive to engine choking characteristic $\mathrm{s}$ during cold-start conditions; indeed, the major portion of CO measured in the federal test procedure occurs during the cold start, prior to catalyst warmup. It may be that the higher values of $\mathrm{CO}$ (and $\mathrm{HC}$, to a lesser extent) in 1976 were the result of timing and carburetion modifications to improve cold-start driveability.

The NO picture in 1975-76 is much the same as in 1973. The addition of oxidation catalysts would not have been expected to cause a change here, and it did not; i. e., the $\mathrm{NO}_{x}$ values are a function of exhaust gas recirculation flow rate and spark retard. 

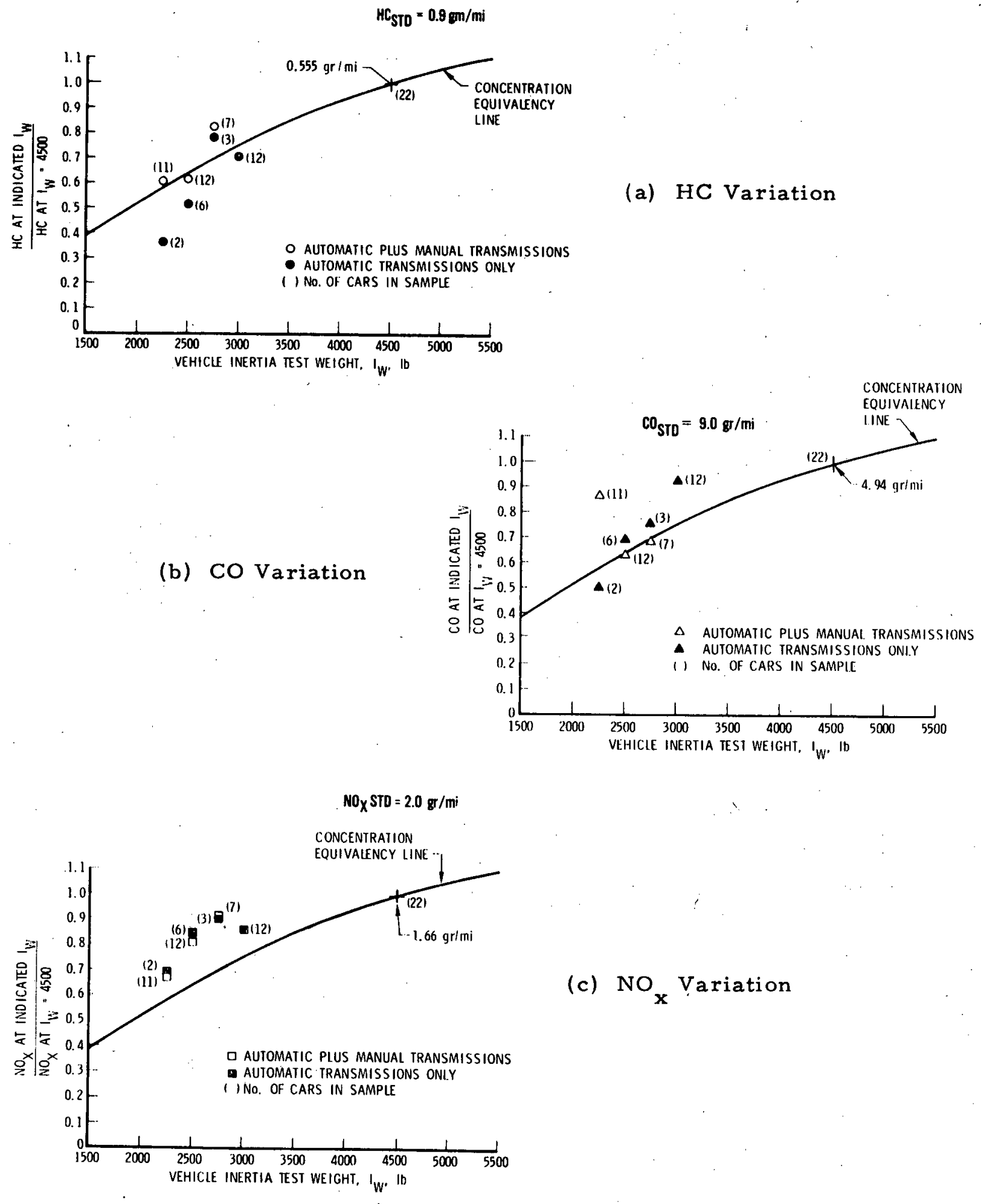

Figure 8. 1975 California Certification Vehicles: Variation of Emissions with Inertia Test Weight, Catalyst Vehicles (Ref. 3) 

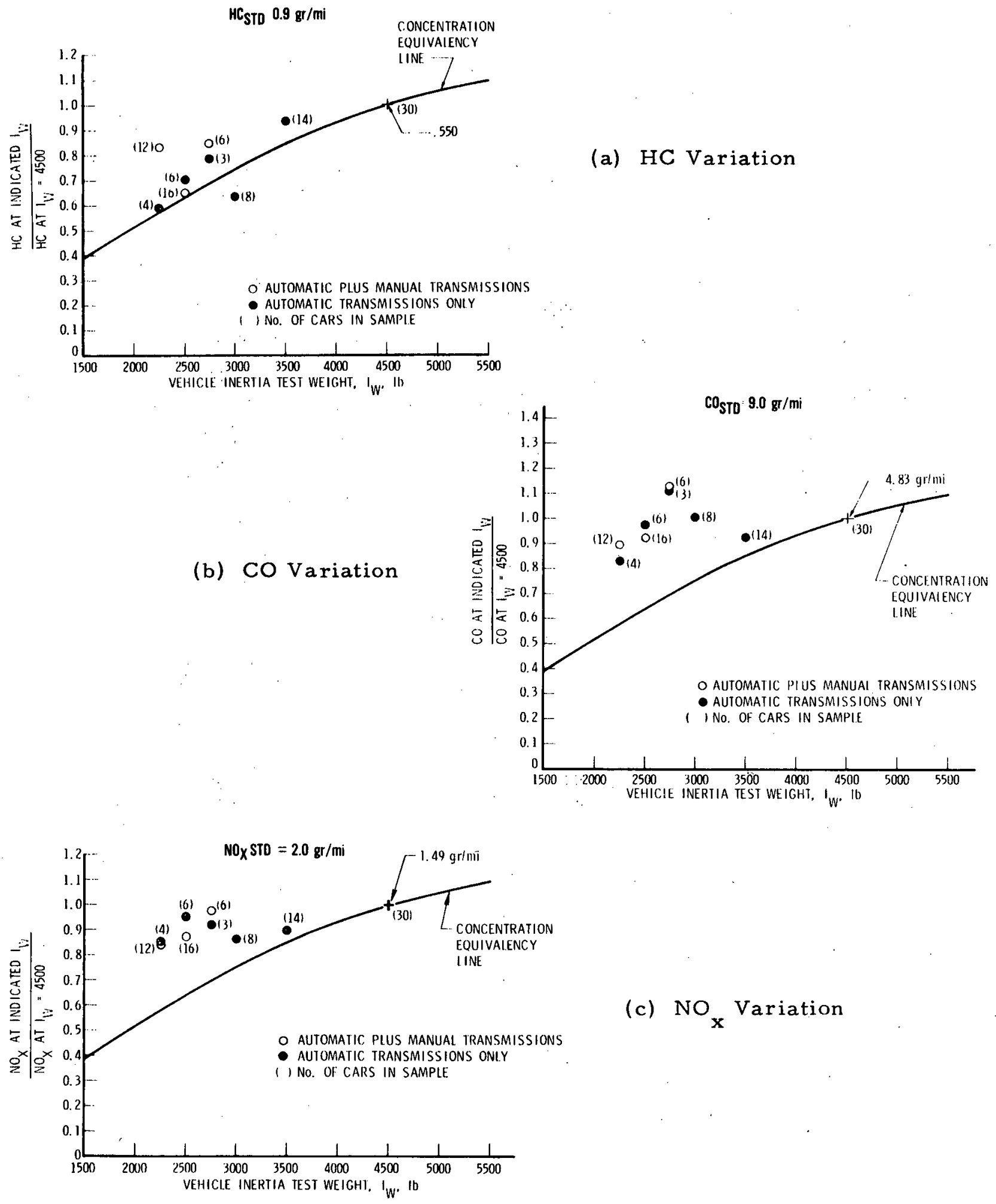

(c) NO ${ }_{\mathbf{x}}$ Variation

Figure 9. 1976 California Certification Vehicles: Variation of Emissions with Inertia Test Weight, Catalyst Vehicles (Ref. 4) 
In summary, then, the small cars are emitting less $\mathrm{HC}$ and $\mathrm{CO}$ than larger cars on a mass, or grams per mile, basis. With the addition of oxidation catalysts, they are emitting $\mathrm{HC}$ and $\mathrm{CO}$ concentrations at nearly the same levels as larger cars. This is as would be expected if the catalytic converters were similarly designed and the input feed gas conditions were controlled to comparable levels. The $\mathrm{NO}_{\mathrm{x}}$ levels of small cars are commensurate with their lower horsepower-to-weight characteristics, which also contributes to the excess of their fuel economy advantage over large vehicles as predictable purely on the basis of equivalent air-fuel ratios and engine thermal efficiency. 


\section{SECTION 4}

\section{CAT AL YST VS. NON-CATALYST EFFECTS}

To more clearly relate the variation in $\mathrm{HC}$ and $\mathrm{NO}_{\mathbf{x}}$ emissions, and fuel economy, under conditions of catalyst vs. non-catalyst use, a simplified analysis was made to permit a graphical demonstration of the advantages of catalyst use in terms of fuel economy trends.

\section{1 LARGE CARS}

In the case of large cars, data from the Ford Motor Company for a $400 \mathrm{CID}, 2.75$ axle ratio, automatic transmission, $5000-1 \mathrm{~b} \mathrm{I}$ vehicle were used to form the basis of the analysis. These data are shown in Figure 10, where fuel economy in miles per gallon is plotted against NO $\mathrm{x}_{\mathrm{f}}$ levels in grams per mile, with parameters of $\mathrm{HC}$ feed gas (i. e., exhaust from the engine that has not been treated by a catalyst or thermal reactor) levels in grams per mile.

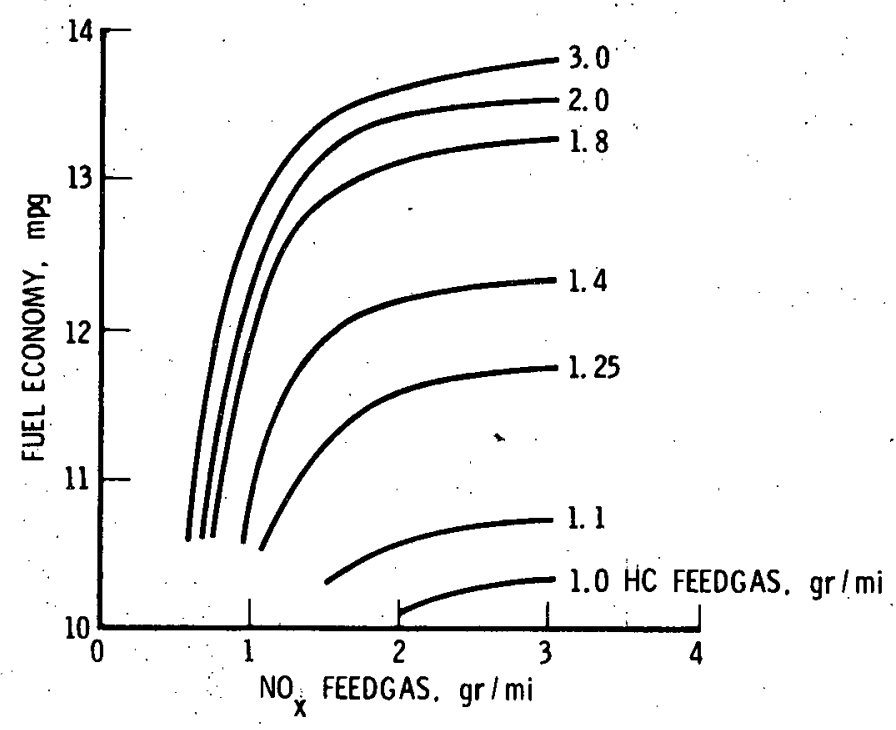

Figure 10. Maximum Fuel Economy CVS-H Projections Study No. 2 (5000-lb Inertia Test Weight Vehicle)(Ref. 5) 
These same data are replotted in Figure 11 (a) as fuel economy vs. HC, with parameters of $\mathrm{NO}_{x}$ level, and labeled "without catalyst." This data map was then converted to the "with catalyst" case shown in the left of the figure by assuming a constant catalyst efficiency of 85 percent. For each case, the 1975-76 federal and California $\mathrm{HC}$ and $\mathrm{NO}_{\mathbf{x}}$ emission standards are indicated by symbols. Figures $11(\mathrm{~b})$ and $11(\mathrm{c})$ more clearly illustrate the fuel economy effects at the federal and California standard levels.

At the federal level [Figure 11(b)], the use of a catalyst would improve fuel economy from 12.75 to: $13.85 \mathrm{mpg}$, an increase of 8.5 percent. At the California level [Figure 11(c)], fuel economy would drop to approximately $9.35 \mathrm{mpg}$ without a catalyst and increase to $13.7 \mathrm{mpg}$ with a catalyst, an improvement of nearly 46 percent. This clearly illustrates why the overwhelming preponderance of catalyst use occurs in larger vehicles. Table 1 shows the catalyst/non-catalyst mix in a sampling of 1976 model year certification vehicles. Of the 499 vehicles surveyed, all vehicles weighing $4000 \mathrm{lb}$ and over incorporated catalysts. In the 3500-1b class, only eight of 68 vehicles did not use catalysts. The situation for the smaller vehicles is discussed below.

\subsection{SMALL CARS}

To illustrate the $\mathrm{HC}, \mathrm{NO}_{\mathrm{x}}$, fuel economy picture for small cars, an analysis was made based on the $I_{w}=2250 \mathrm{lb}$ case. The "without catalyst" data for the large car in Figure 11(a) were scaled to the 2250-1b I case with the following assumptions:

a. The HC level in parts per million of the small car was the same as that of the large car. For the $I_{w}=2250-1 b$ case, this means the grams per mile of $\mathrm{HC}$ emitted is approximately 60 percent that of the large car, based on the equal concentration equivalency line of Figure 3 .

b. At the same HC parts-per-million level, the $\mathrm{NO}_{x}$ mass emissions of the $I_{w}=2250-1 b$ car were 75 percent of those of the large car. This was based on the general NO $\mathrm{Ns}_{\mathrm{x}}$ $I_{w}$ trends of Figures $7,8(c)$, and $9(\mathrm{c})$. 


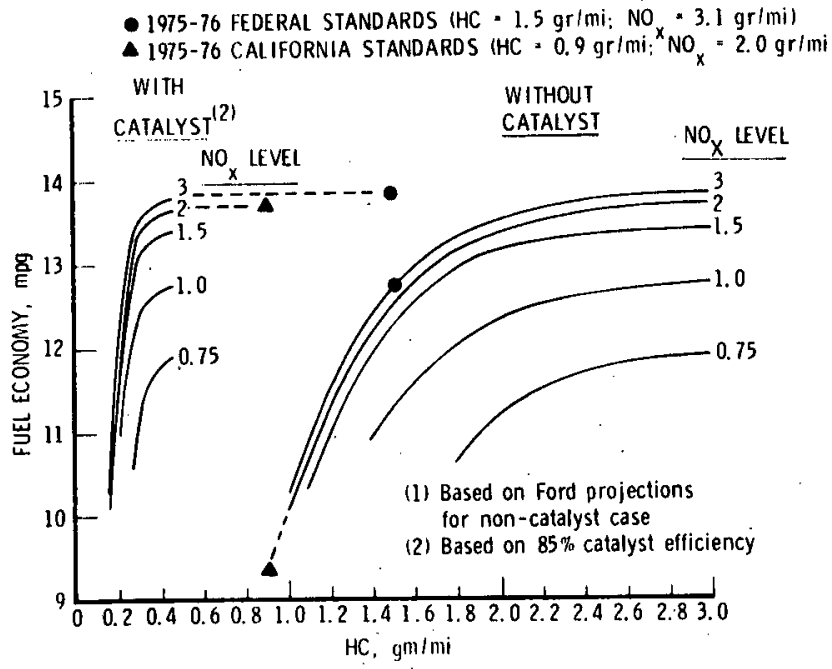

(a) Federal/California Emission Levels(1)

(b) Federal Emission Levels
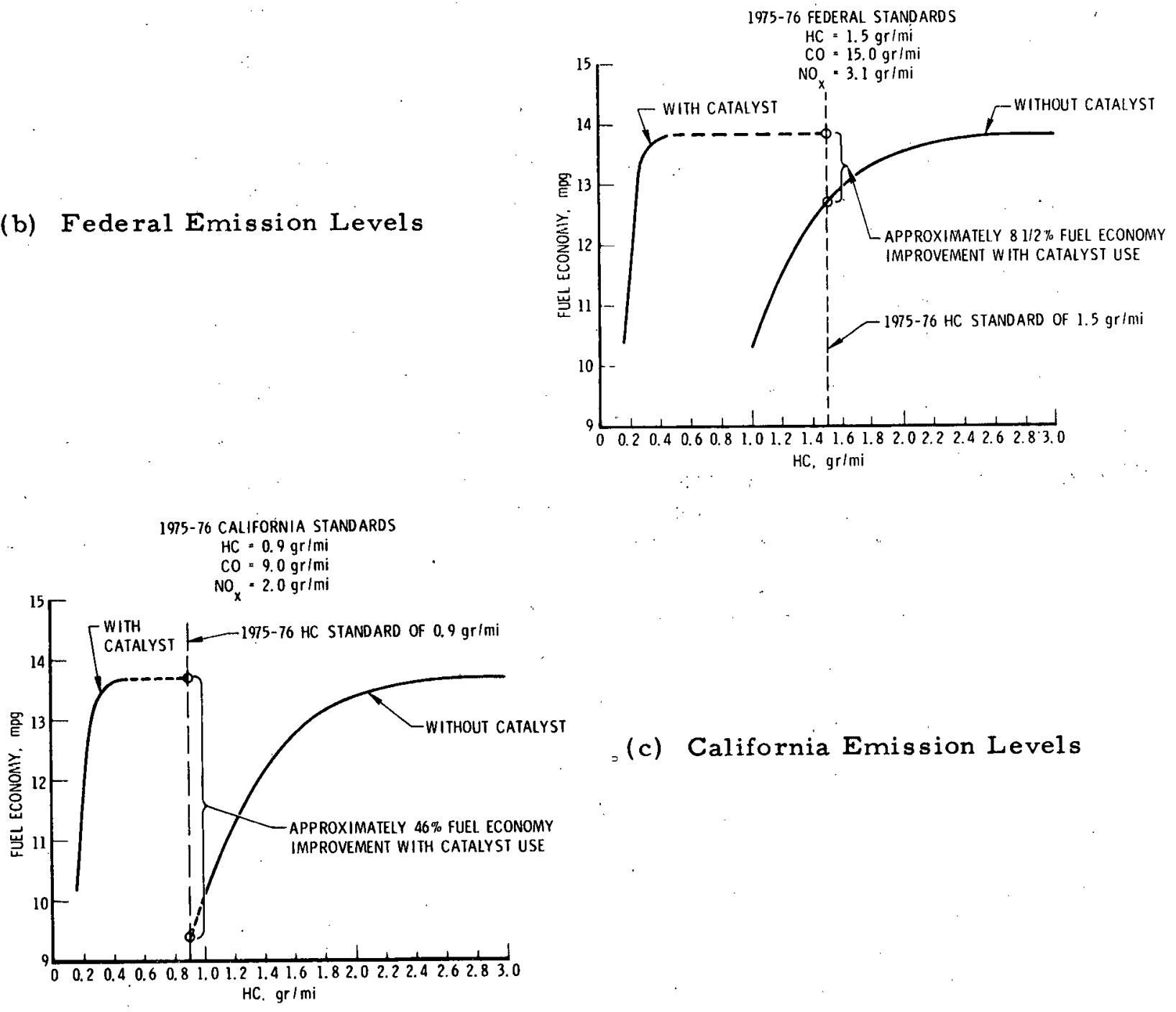

(c) California Emission Levels

Figure 11. Impact of Catalyst Use on Fuel Economy at 1975-76 Emission Levels (5000-1b Inertia Test Weight Vehicle) 
Table 1. 1976 Certification Vehicles: Catalyst vs. Non-catalyst Mix (Ref. 4)

\begin{tabular}{|c|c|c|c|c|c|c|}
\hline \multirow{2}{*}{$\begin{array}{c}\text { Inertia Test } \\
\text { Weight, } \\
\text { lb }\end{array}$} & \multicolumn{2}{|c|}{ California } & \multicolumn{2}{|c|}{49 States } & \multicolumn{2}{|c|}{ All States } \\
\hline & $\begin{array}{c}\text { With } \\
\text { Catalyst }\end{array}$ & $\begin{array}{l}\text { Without } \\
\text { Catalyst }\end{array}$ & $\begin{array}{c}\text { With } \\
\text { Catalyst }\end{array}$ & $\begin{array}{l}\text { Without } \\
\text { Catalyst }\end{array}$ & $\begin{array}{c}\text { With } \\
\text { Catalyst }\end{array}$ & $\begin{array}{l}\text { Without } \\
\text { Catalyst }\end{array}$ \\
\hline 2000 & 0 & 0 & 0 & 4 & 0 & 4 \\
\hline 2250 & 16 & 0 & 6 & 9 & 22 & 9 \\
\hline 2500 & 16 & 0 & 0 & 18 & 16 & 18 \\
\hline 2750 & 6 & 3 & 6 & 13 & 12 & 16 \\
\hline 3000 & 34 & 0 & 30 & 25 & 64 & 25 \\
\hline 3500 & 27 & 0 & 33 & 8 & 60 & 8 \\
\hline 4000 & 27 & 0 & 49 & 0 & 76 & 0 \\
\hline 4500 & 31 & 0 & 42 & 0 & 73 & 0 \\
\hline 5000 & 19 & 0 & 31 & 0 & 50 & 0 \\
\hline \multirow[t]{3}{*}{5500} & 22 & 0 & 24 & 0 & 46 & 0 \\
\hline & 198 & 3 & 221 & 77 & 419 & 80 \\
\hline & \multicolumn{2}{|c|}{201} & \multicolumn{2}{|c|}{298} & \multicolumn{2}{|c|}{499} \\
\hline
\end{tabular}


The results of this procedure are shown as the "without catalyst" case in Figure 12(a). The "with catalyst" case was produced from the se data using a catalyst efficiency of 85 percent. As can be seen, compared to the large car in Figure 11(a) the small car is much less sensitive to variations in both $\mathrm{HC}$ and $\mathrm{NO}_{\mathbf{x}}$. Again, for each case, the 1975-76 federal and California HC and $\mathrm{NO}_{x}$ emission standards are indicated by symbols. Figures $12(\mathrm{~b})$ and $12(\mathrm{c})$ summarize the fuel economy effects at the federal and California standard levels.

In contrast to the case of the large car, at the federal level [Figure $12(\mathrm{~b})]$ the use of a catalyst in the small car only improves the fuel economy from 27.7 to $28.0 \mathrm{mpg}$, or one percent. Thus, the re is a little incentive to use a catalyst in many smaller cars to meet federal standards. This is shown in Table 1 where, at $\mathrm{I}_{\mathrm{w}}=2750 \mathrm{lb}$ and below, only 12 of the 56 certification vehicles use catalysts in the 49 -state case.

On the other hand, when California standards are considered [Figure $12(\mathrm{c})]$, the use of a catalyst can improve fuel economy from $25.1 \mathrm{mpg}$ to $27.6 \mathrm{mpg}$, or ten percent. Thus, there is a clear incentive to use catalysts on small cars in California. This also is indicated in Table 1 where, for the California case, 38 of the 41 certification vehicles at $I_{w}=2750 \mathrm{lb}$ and below incorporate catalysts.

\section{3 SUMMARY REMARKS}

The foregoing comparisons and the data of Figures 11 and 12 serve to illustrate that both $\mathrm{HC}$ and $\mathrm{NO}_{\mathbf{x}}$ levels can have a strong influence on resultant vehicle fuel economy in both large and small cars. In the case of large cars, the fuel economy loss attendant to the non-use of catalysts for HC control is sufficiently high (approximately 8.5 percent) at the federal emission level $(1.5 \mathrm{gr} / \mathrm{mi})$ to effectively force their use. At the California level $(0.9 \mathrm{gr} / \mathrm{mi})$, the non-use of catalysts for $\mathrm{HC}$ control could result in a prohibitive fuel economy loss (approximately 46 percent). For the longer term control of $\mathrm{HC}$ (projected standard of $0.41 \mathrm{gr} / \mathrm{mi}$ ), the catalyst is the only available emission control technique for the conventional spark ignition engine. 


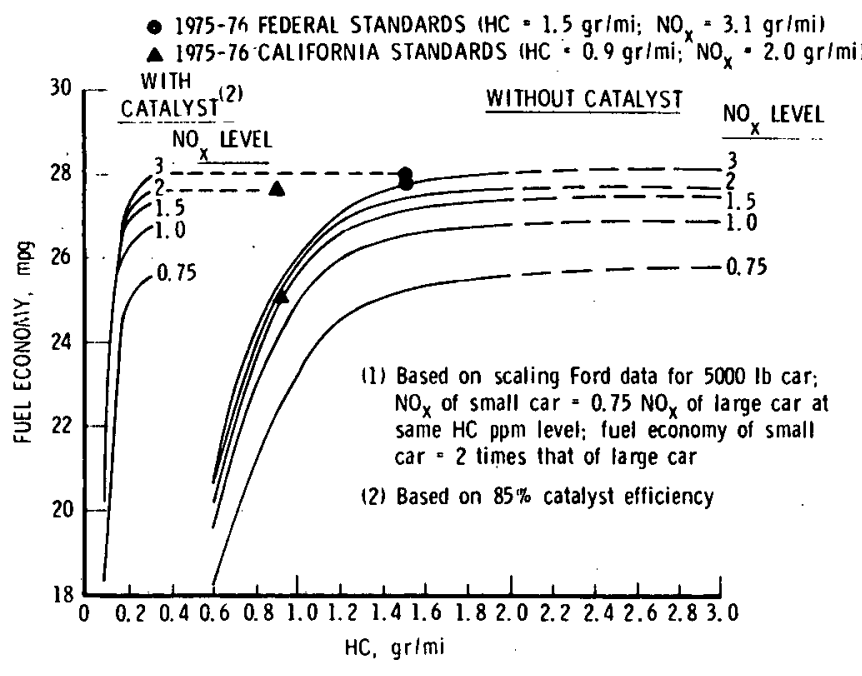

(a) Federal/California Emission Levels(1)
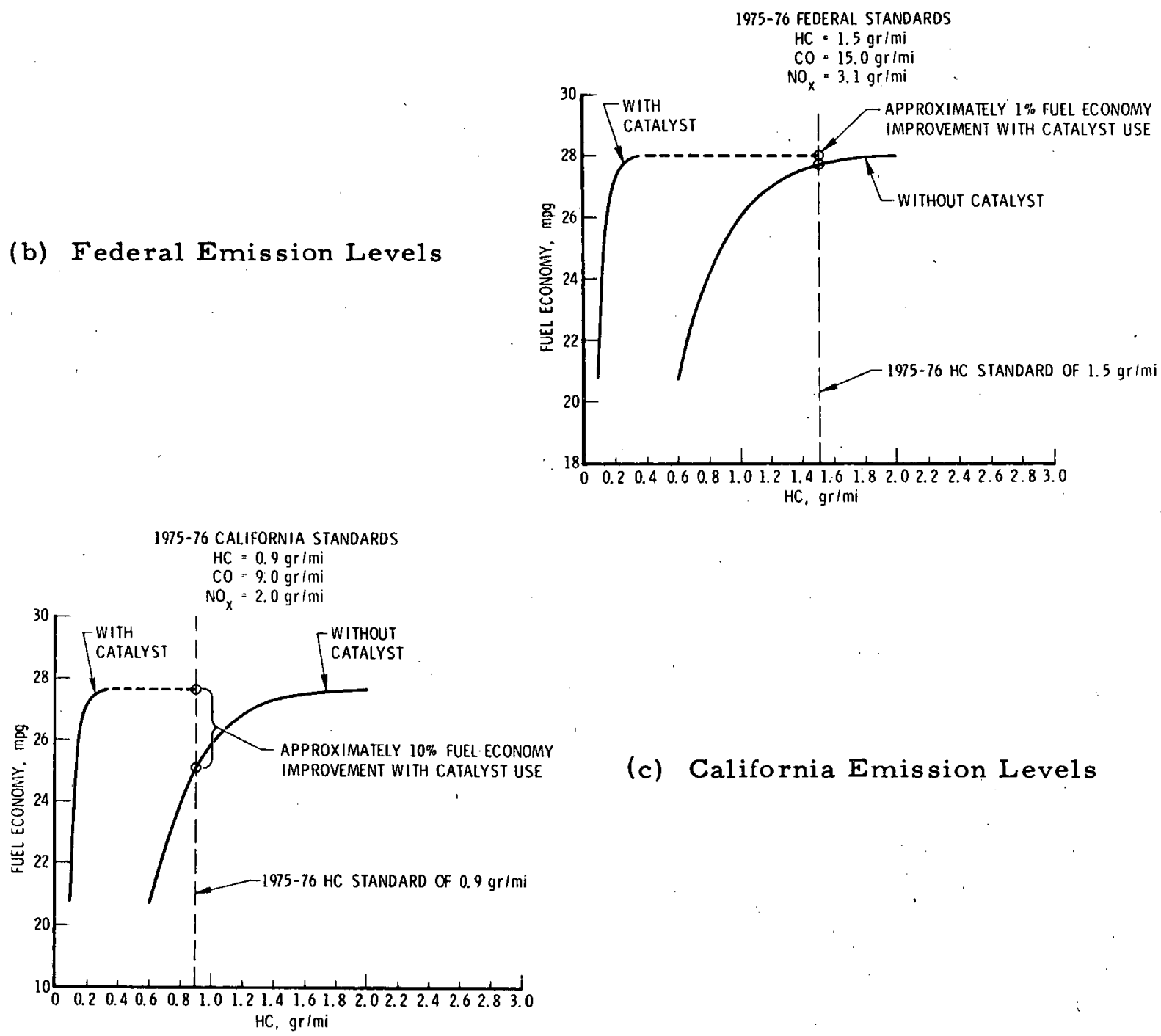

(c) California Emission Levels

Figure 12. Impact of Catalyst Use on Fuel Economy at 1975-76 Emission Levels (2250-1b Inertia Test Weight Vehicle) 
In the case of small cars, the current federal standard for HC $(1.5 \mathrm{gr} / \mathrm{mi})$ does not effectively force the use of catalysts, whereas the California level $(0.9 \mathrm{gr} / \mathrm{mi})$ does so more forcefully by providing a ten percent fuel economy improvement potential. For the projected HC standard of $0.41 \mathrm{gr} / \mathrm{mi}$, the small car with a conventional engine must also incorporate either catalysts or thermal reactors for more stringent control.

In either case, large or small car, and federal or California HC standard, the $\mathrm{NO}_{\mathbf{x}}$ standard has a significant impact on vehicle fuel economy, as shown in Figures $11(\mathrm{a})$ and 12(a). The smaller car is less sensitive to it, but both classes show significant losses in fuel economy as the standard is lowered below the current 3.1 and $2 \mathrm{gr} / \mathrm{mi}$ respective levels.

In summary, if the projected HC standard of $0.41 \mathrm{gr} / \mathrm{mi}$ is implemented, it is most likely that both large and small cars will be forced to incorporate oxidation catalysts in order to meet it without suffering a prohibitively high fuel economy penalty. This use of catalysts should also result in the smaller cars emitting a proportionately lower amount of HC.

On this basis, then, no further type of regulation beyond the contemplated $\mathrm{HC}=0.41 \mathrm{gr} / \mathrm{mi}$ standard would be required to force the use of catalysts in smaller cars with the attendant emission and fuel economy benefits noted above. Therefore, ERDA should support efforts to ensure that this standard is implemented. 
THIS PAGE

WAS INTENTIONALLY

LEFT BLANK 


\section{REFERENCES}

1. Federal Register, Vol. 33, No. 108, Tuesday, June 4, 1968, Page 8315

2. "Federal Certification Test Results for 1973 Model Year," Federal Register, Vol. 38, No. 84, Part III, Environmental Protection Agency, Washington, D. C., May 2, 1973

3. "1975 Gas Mileage Guide for New Car Buyers," EPA/FEA, February 1, 1975

4. "1976 Gas Mileage Guide for New Car Buyers," EPA/FEA, October 17, 1975

5. "Supplement in Response to Request of EPA Administrator for Information Relating to The Relationship of Vehicle Fuel Economy and Emission Standards Beyond Those Applicable to 1977 Model Year Vehicles," Ford Motor Company, 14 January 1975 